\title{
Heterogeneous Photo-Fenton Removal of Methyl Orange Using the Sludge Generated in Dyeing Wastewater as Catalysts
}

\author{
Xu Liu ${ }^{1,2}$, Hui-Lai Liu ${ }^{1,2}$, Kang-Ping Cui ${ }^{1, *}$, Zheng-Liang Dai ${ }^{3}$, Bei Wang ${ }^{3}$ and Xing Chen ${ }^{1,2, * \mathbb{D}}$ \\ 1 Key Laboratory of Nanominerals and Pollution Control of Higher Education Institutes, \\ School of Resources and Environmental Engineering, Hefei University of Technology, Hefei 230009, China; \\ akira0519@sina.com (X.L.); LiuHuilai1996@163.com (H.-L.L.) \\ 2 Key Laboratory of Aerospace Structural Parts Forming Technology and Equipment of Anhui Province, \\ Institute of Industry and Equipment Technology, Hefei University of Technology, Hefei 230009, China \\ 3 Anqing Changhong Chemical Co., Ltd., Anqing 246002, China; zl_dai@163.com (Z.-L.D.); \\ 13855694589@163.com (B.W.) \\ * Correspondence: cuikangping@hfut.edu.cn (K.-P.C.); xingchen@hfut.edu.cn (X.C.)
}

Citation: Liu, X.; Liu, H.-L.; Cui, K.-P.; Dai, Z.-L.; Wang, B.; Chen, X. Heterogeneous Photo-Fenton Removal of Methyl Orange Using the Sludge Generated in Dyeing Wastewater as Catalysts. Water 2022, 14, 629. https://doi.org/10.3390/ w14040629

Academic Editor: Christos Akratos

Received: 10 January 2022

Accepted: 15 February 2022

Published: 18 February 2022

Publisher's Note: MDPI stays neutral with regard to jurisdictional claims in published maps and institutional affiliations.

Copyright: (C) 2022 by the authors. Licensee MDPI, Basel, Switzerland. This article is an open access article distributed under the terms and conditions of the Creative Commons Attribution (CC BY) license (https:// creativecommons.org/licenses/by/ $4.0 /)$.

\begin{abstract}
The disposal process of iron-containing sludge often leads to secondary pollution. Pyrolysis of sludge appears to be less polluting than conventional methods. Herein, the heterogeneous photo-Fenton catalysts were prepared using sludge generated in the dyeing wastewater through a simple one-step pyrolysis route. The catalysts were characterized by XRD, FT-IR, XPS, EDS, BET, and SEM. The batch experiments for methyl orange (MO) degradation were performed to evaluate the efficiency and stability of the catalysts. Among the catalysts prepared, FeCN-300 exhibited the best degradation efficiency with $92 \%$ removal of the pollutant and good stability, with approximately $90 \%$ removal of the pollutant after five cycles. The $\bullet \mathrm{OH}$ was identified as the dominant reactive species. This work provides a reasonable resource utilization of iron-containing sludge.
\end{abstract}

Keywords: icon-containing sludge; photo-Fenton; methyl orange; resource utilization

\section{Introduction}

Dyeing wastewater has a complex composition, deep color, and high pollutant concentration [1-3], which is often pretreated using the Fenton method before biochemical treatment, leading to a large amount of iron-containing sludge [4-6]. Iron-containing sludge is a kind of solid waste, which is usually treated by processes involving landfill, incineration, and other methods. However, dioxins, $\mathrm{NOx}, \mathrm{SO}_{2}$, and heavy metals released during the incineration of sludge can cause serious air pollution, and the landfill process may cause secondary pollution of groundwater and soil [7-10]. Therefore, reasonable resource utilization of sludge plays a critical role in environment treatment research.

In recent years, sludge pyrolysis has received extensive attention compared with traditional methods since it can concentrate heavy metals into solid carbon-containing residues, and convert around half of the organic matter into liquid fuels and chemical raw materials [11-13]. Research on the preparation of heterogeneous Fenton catalysts through the pyrolysis of sludge has been continuously reported. Yuan et al. [14] developed SS-Fe-350, which exhibited an excellent degradation of Rhodamine B in a photo-Fenton reaction. Huang et al. [15] produced sewage sludge biochar by using microwave pyrolysis at different microwave powers and investigated their degradation of trichloroethylene in heterogeneous Fenton systems. Gan et al. [16] prepared Fe-rich biochar with multivalent iron compounds $\left(\mathrm{Fe}^{0}, \mathrm{Fe}_{0.95} \mathrm{C}_{0.05}, \mathrm{Fe}_{3} \mathrm{O}_{4}\right.$, and $\left.\mathrm{FeAl}_{2} \mathrm{O}_{4}\right)$ from sludge cake, which showed remarkable catalytic efficiency for 4-chlorophenol degradation through both homogeneous and heterogeneous Fenton reactions. Although a variety of catalysts have been prepared from sewage sludge, as far as we know, the preparation of heterogeneous photo-Fenton 
catalysts using sludge from dyeing wastewater has not yet been reported. How to recycle this iron-containing sludge to achieve the goal of treating waste with waste will be described below.

MO is a typical azo dye that can be used for printing and dyeing textiles. It is classified as an acutely toxic compound and a mutagenic substance in the GHS classification [17-20]. In previous studies on degrading dyeing wastewater, $\mathrm{MO}$ was often selected as the modeling pollutant for evaluation of catalysts [21,22].

In this study, the iron-containing sludge generated in the dyeing wastewater was converted into a heterogeneous catalyst through a simple thermal treatment process, which was applied to the study of photo-Fenton degradation of azo dye wastewater. The obtained catalysts were characterized by X-ray diffraction (XRD), Fourier infrared spectrometer (FT-IR), X-ray photoelectron spectrometer (XPS), energy dispersive X-ray spectrometer (EDS), Brunauer-Emmett-Teller theory (BET), and scanning electron microscopy (SEM). The parameters for the photo-Fenton process (catalyst type, pollutant initial concentration, hydrogen peroxide initial concentration) were studied through the degradation of MO.

\section{Materials and Methods}

\subsection{Materials}

All reagents used in this study were analytical grade, and were used without further purification. Methyl orange (MO) and hydrogen peroxide $\left(\mathrm{H}_{2} \mathrm{O}_{2}, 30 \%, w / w\right)$ were purchased from Shanghai Chemical Reagent Co. Ltd. Silver nitrate $\left(\mathrm{AgNO}_{3}\right)$; tert-butanol (TBA), ethylenediaminetetraacetic acid disodium salt (EDTA-2Na), 1,4-benzoquinone (BQ), and 2,2,6,6-tetramethylpiperidine-1-oxyl (TEMPO) were bought from Shanghai Sinopharm Chemical Reagent Co. Ltd. 5,5-dimethyl-1-pyrroline-N-oxide (DMPO) was obtained from Sigma-Aldrich (Saint Louis, MO, USA). Ultrapure deionized water (conductivity $\sim 18.25 \mathrm{M} \Omega \cdot \mathrm{cm}$ ) was used throughout the experiments.

\subsection{Catalyst Preparation}

The catalyst was derived from the iron-containing sludge from the sedimentation tank of a chemical factory's wastewater treatment facility in Anqing city. Firstly, the sludge was dried in the oven at $80{ }^{\circ} \mathrm{C}$ for $12 \mathrm{~h}$. Secondly, the dried sludge was ground into powder and passed through a 100-mesh screen. Thirdly, $5 \mathrm{~g}$ of the obtained material was put in a corundum crucible. Under the protection of a nitrogen atmosphere, the material was heated to a certain temperature at a rate of $2.4^{\circ} \mathrm{C} / \mathrm{min}$ and maintained for $3 \mathrm{~h}$ in order to obtain a stabilized material. Then, the material was naturally cooled to room temperature. The catalysts calcined at different temperatures were marked with FeCN-0 (not calcined), FeCN-300 (calcined at $300{ }^{\circ} \mathrm{C}$ ), FeCN-400 (calcined at $400{ }^{\circ} \mathrm{C}$ ), and FeCN-500 (calcined at $\left.500{ }^{\circ} \mathrm{C}\right)$, respectively.

\subsection{Catalyst Characterization}

The morphology and element composition of the catalysts were studied using an SU-8020 thermal field emission scanning electron microscope (SEM; Hitachi, Tokyo, Japan) and an energy dispersive X-ray spectrometer (EDS; Hitachi, Tokyo, Japan). An X-ray diffractometer (XRD; PANalytical X'Pert Pro, Almelo, The Netherlands) was used to analyze the crystalline structure of the catalyst within the range of $5^{\circ}$ to $90^{\circ}$ at a step of 0.2 . The chemical bonds of the composite were determined by a Fourier infrared spectrometer (FT-IR; Thermo Nicolet, Waltham, MA, USA) in the $4000-400 \mathrm{~cm}^{-1}$ wave range with a resolution of $2 \mathrm{~cm}^{-1}$. The surface chemical properties of the samples were studied by X-ray photoelectron spectrometry (XPS; Thermo, Waltham, MA, USA). All XPS data analytics were performed using dedicated code (PeakFit V4.12). The specific surface area and the pore size distribution of the samples were obtained by Brunauer-Emmett-Teller analysis (Autosorb-IQ3, Quantachrome, Boynton Beach, FL, USA). 


\subsection{Photo-Fenton Experiments}

The photocatalytic performance of the catalyst was evaluated by the degradation of $\mathrm{MO}$ in an aqueous solution. The test tubes were evenly distributed in the grooves on the turntable of the photoreactor (XPA-7; Xujiang Electromechanical Plant, Nanjing, China), and rotated at a constant speed after the reaction started. The light source was in the center of the turntable, and the distance to each test tube was $7 \mathrm{~cm}$. To reduce iron leaching and enhance catalyst stability, all experiments were conducted at a neutral $\mathrm{pH}$. In the experiment, $10 \mathrm{mg}$ catalyst was added to a $50 \mathrm{~mL} \mathrm{MO}$ aqueous solution with an initial concentration of $50 \mathrm{mg} / \mathrm{L}$. The sample was added to the solution and reacted in darkness for $30 \mathrm{~min}$ to achieve adsorption-desorption equilibrium, after which the photoreactor was exposed to a $300 \mathrm{~W}$ mercury lamp. A certain concentration of $\mathrm{H}_{2} \mathrm{O}_{2}$ was added before irradiation, $1 \mathrm{~mL}$ of the reaction solution was taken every $30 \mathrm{~min}$, and a $0.45 \mathrm{~mm}$ filter membrane was used to remove the catalyst.

The concentration of MO was measured by a UV-vis spectrophotometer (UV 2600; Shimadzu, Kyoto, Japan) at $\lambda \max 465 \mathrm{~nm}$. In this work, to ensure the accuracy of the measurement results, we diluted the solution to be tested by 2.5 times and measured its absorbance at the maximum absorption wavelength (in the comparison experiment of the initial concentration of $\mathrm{MO}$, the solutions with initial concentration of $10,25,50,75$, and $100 \mathrm{mg} / \mathrm{L}$ were diluted by 1, 2.5, 5, 7.5, and 10 times, respectively, and then measured). The total organic carbon (TOC) in the samples was determined by a TOC/TN analyzer (Multi $\mathrm{N} / \mathrm{C} 3100)$. The presence of $\bullet \mathrm{OH}$ was determined by electron spin resonance spectrometer (ESR; JES-FA200, Tokyo, Japan), using DMPO as scavengers.

For the recycling test, the FeCN-300 catalyst was collected after each run of photoFenton process, washed with ultrapure deionized water, dried for $8 \mathrm{~h}$ in an oven at $60{ }^{\circ} \mathrm{C}$, and then collected for the next run.

\section{Results}

\subsection{Characterization of the Prepared Catalyst}

The morphology of the FeCN-0 and the FeCN-300 catalysts are shown in Figure 1a,b. The SEM micrograph demonstrates that the FeCN-300 is more compact and regular than the FeCN-0. A micron-level structure with severe agglomeration on the surface is also observed. The EDS analysis reveals the main elements of the FeCN-300 catalyst are Fe, C, $\mathrm{N}$, and $\mathrm{O}$ (Figure 1c).
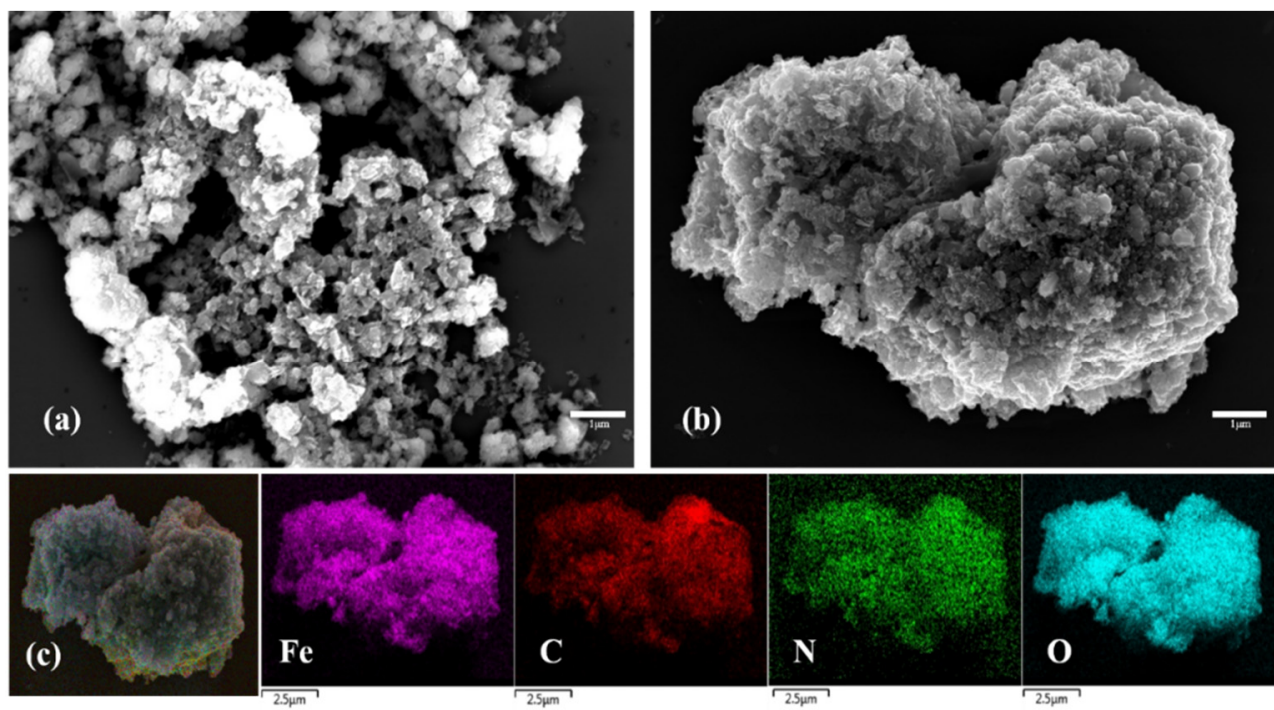

Figure 1. SEM images of FeCN-0 (a) and FeCN-300 (b); Elemental mapping images of FeCN-300 (c) for $(\mathrm{Fe}),(\mathrm{C}),(\mathrm{N}),(\mathrm{O})$. 
The crystalline properties of the FeCN-0 and the FeCN-300 catalysts were analyzed using XRD measurements. As presented in Figure 2a, the diffraction peaks of the FeCN-300 at $2 \theta=35.6^{\circ}, 54.0^{\circ}$ and $62.6^{\circ}$ corresponding to the (222), (422), and (531) crystal planes, which confirms the presence of $\mathrm{Fe}_{3} \mathrm{O}_{4}$ nanoparticles in the FeCN-300 catalyst (JCPDS 75-0033) [23].
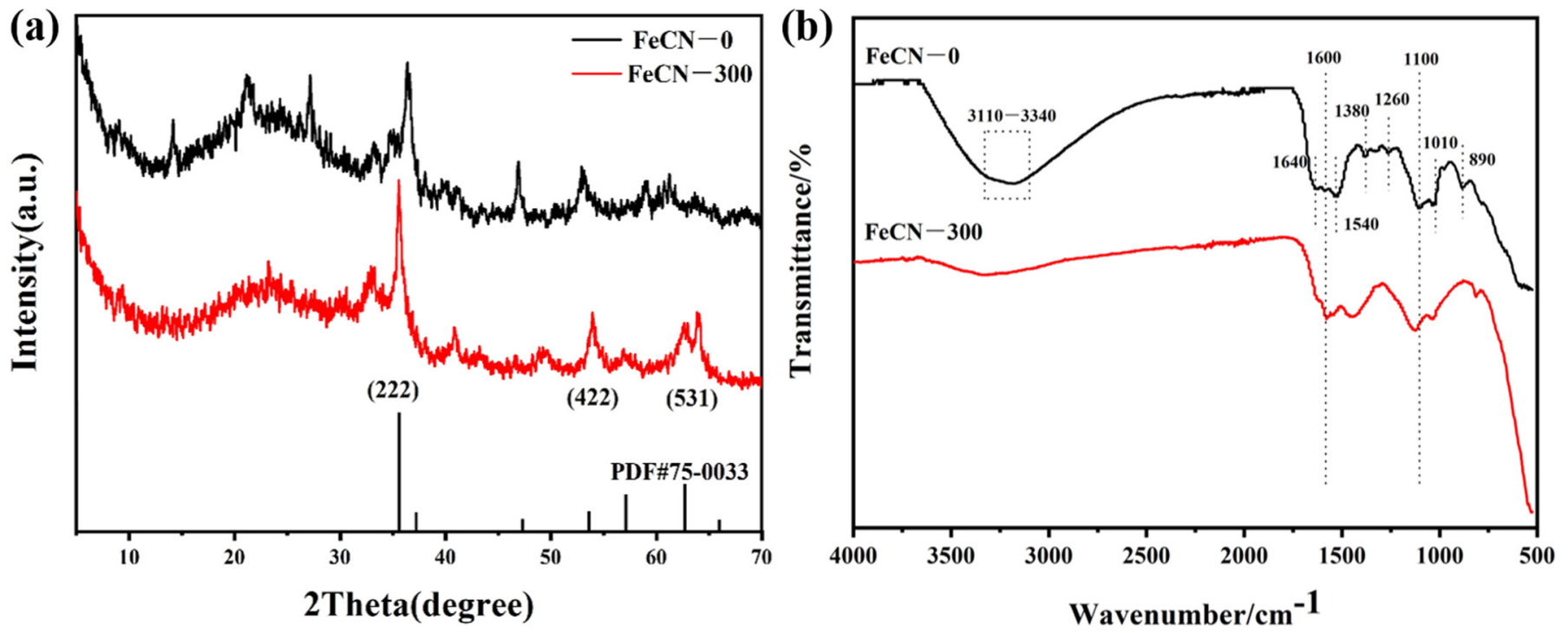

Figure 2. XRD patterns (a) and FT-IR spectra (b) of FeCN-0 and FeCN-300.

FT-IR spectra of the FeCN-0 and the FeCN-300 catalysts are shown in Figure $2 \mathrm{~b}$. The wide absorption band of $3110-3340 \mathrm{~cm}^{-1}$ and the peak at $1640 \mathrm{~cm}^{-1}$ can be attributed to the $\mathrm{O}-\mathrm{H}$ stretching vibration and bending vibration, respectively [24,25], which significantly reduced after calcination. The peaks at $1600 \mathrm{~cm}^{-1}$ and $1540 \mathrm{~cm}^{-1}$ are ascribed to the stretching vibration of $C=C$ [26]. The peak at $890 \mathrm{~cm}^{-1}$ confirms the aromatic ring structure in the FeCN-0 [27], which decreased in the FeCN-300, indicating that the unsaturated structure of the material disappeared during the pyrolysis process.

XPS analysis was used to determine the surface chemical properties of the FeCN-0 and the FeCN-300 catalysts, as illustrated in Figure 3. For Fe 2p spectra of the FeCN-300, the main peaks appeared at $723.9 \mathrm{eV}$ and $710.5 \mathrm{eV}$, corresponding to the Fe $2 \mathrm{p} 1 / 2$ and Fe 2 p3/2 binding energy of $\mathrm{Fe}^{2+}$ ions. The peaks observed at $726.2 \mathrm{eV}$ and $712.3 \mathrm{eV}$ can be attributed to the $\mathrm{Fe} 2 \mathrm{p} 1 / 2$ and $\mathrm{Fe} 2 \mathrm{p} 3 / 2$ binding energy of $\mathrm{Fe}^{3+}$ ions $[28,29]$. Compared with the FeCN-0, the content of $\mathrm{Fe}^{2+}$ increased, while that of $\mathrm{Fe}^{3+}$ decreased, indicating the reduction of iron occurred in the calcination process under nitrogen atmosphere. This might be the reason for the formation of $\mathrm{Fe}_{3} \mathrm{O}_{4}$ in the $\mathrm{FeCN}-300$, which is consistent with the results of the XRD analysis. The O 1s spectra of the FeCN-300 can be fit to three peaks with binding energies of $529.8 \mathrm{eV}, 531.5 \mathrm{eV}$, and $532.8 \mathrm{eV}$, which can be attributed to Fe-O, $\mathrm{C}-\mathrm{O}$, and $\mathrm{C}=\mathrm{O}$, respectively [30]. Compared with the FeCN-0, the area of $\mathrm{C}=\mathrm{O}$ decreased, while C-O increased in the FeCN-300 catalyst.

Figure 4 shows the $\mathrm{N}_{2}$ adsorption/desorption isotherms of the FeCN-0 and the FeCN300 catalysts. According to the IUPAC classification of adsorption isotherms, both of them exhibit the characteristic of type II, indicating the macroporous property of catalysts [31]. Table 1 shows the pore structure parameters of the FeCN-0 and the FeCN-300. After calcination, the specific surface area, pore size, and pore volume of the catalyst increased by $43.4 \%, 5.3 \%$, and $32.7 \%$, respectively. The specific surface area and pore size of the calcined catalyst increased, resulting in the improved adsorption efficiency of pollutants. 
(a)

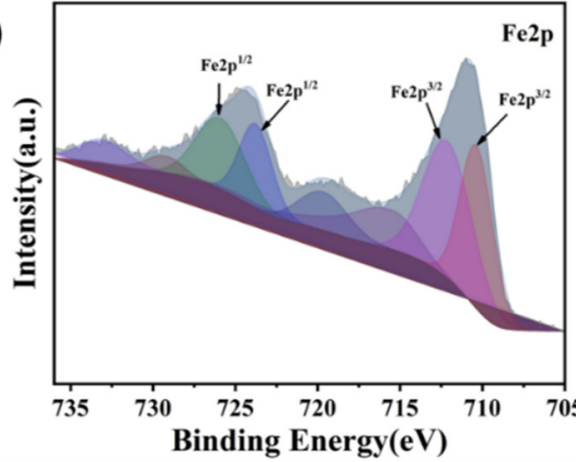

(b)

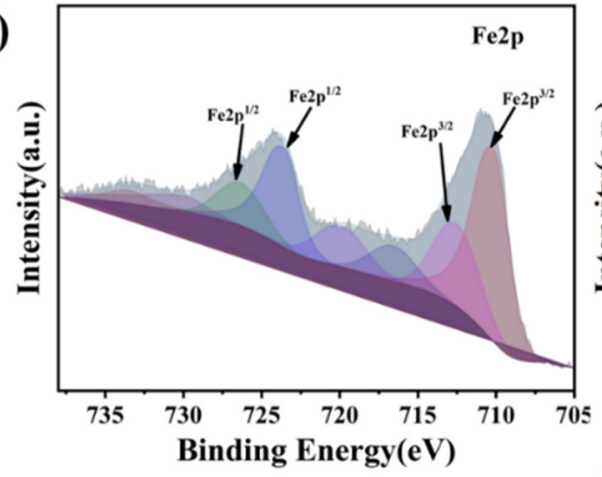

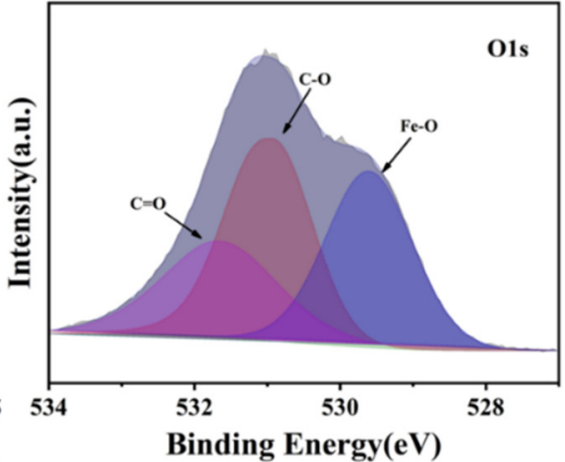

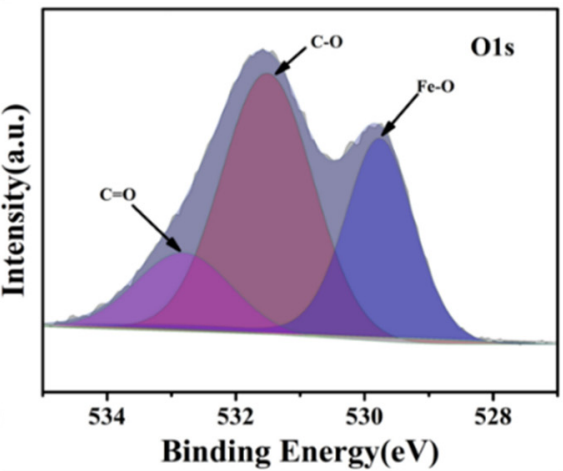

Figure 3. High solution Fe 2p and O 1s of (a) FeCN-0 and (b) FeCN-300.

(a)

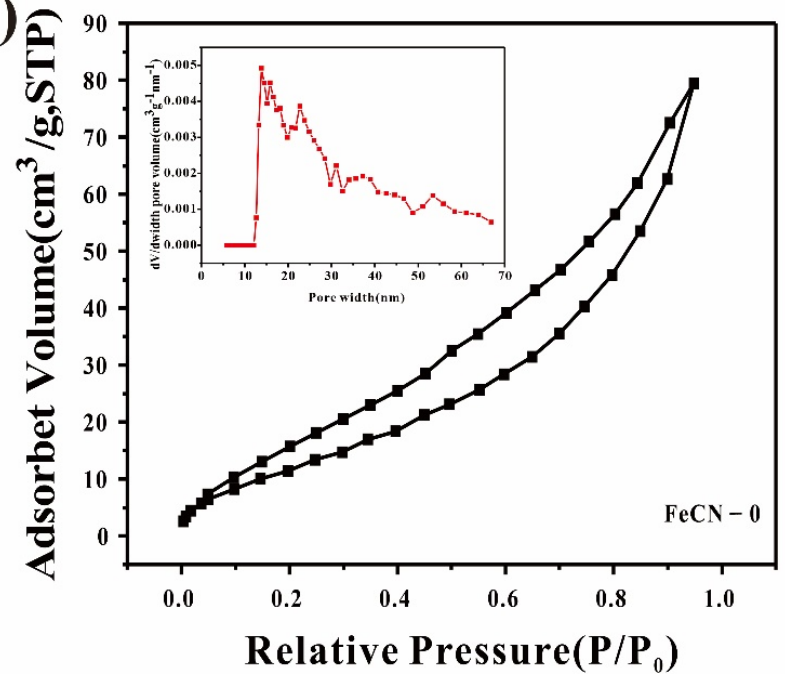

(b)

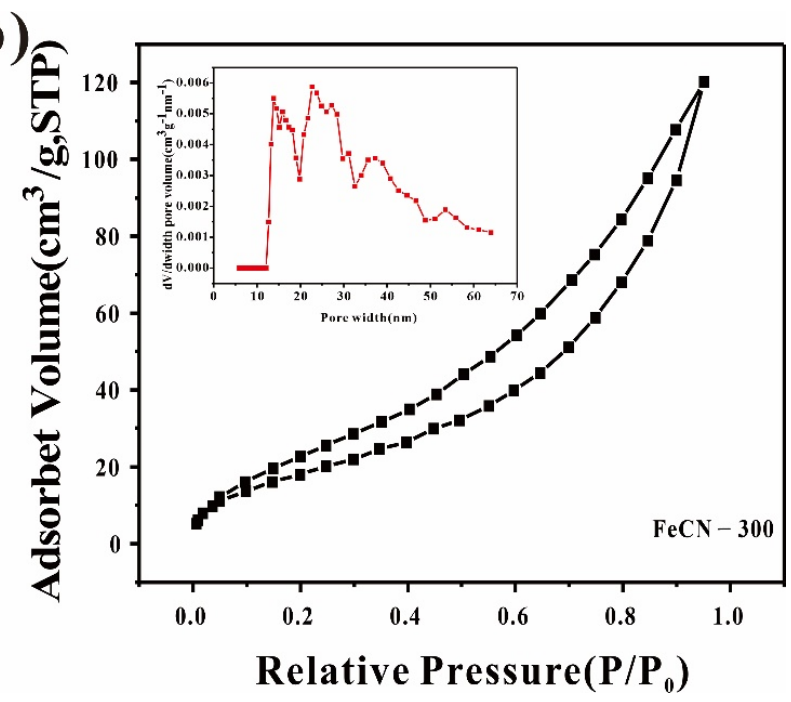

Figure 4. The $\mathrm{N}_{2}$ adsorption-desorption isotherm and the corresponding pore size distribution curves (inset) of (a) FeCN-0 and (b) FeCN-300.

Table 1. The specific surface area and pore size distribution of FeCN-0 and FeCN-300.

\begin{tabular}{cccc}
\hline Catalyst & $\mathrm{S} /\left(\mathbf{m}^{2} / \mathbf{g}\right)$ & $\mathrm{D} /(\mathbf{n m})$ & $\mathrm{V} /(\mathrm{cc} / \mathbf{g})$ \\
\hline FeCN-0 & 50.425 & 48.782 & 0.105 \\
\hline FeCN-300 & 72.331 & 51.391 & 0.156 \\
\hline
\end{tabular}

\subsection{Photo-Fenton Degradation of $M O$}

A series of catalysts were prepared under different thermal treatment temperatures. The degradation efficiency of MO during adsorption and photo-Fenton experiments was investigated under different conditions, with the absorbance at the maximum absorption 
wavelength and removal results shown in Figure S1 and Figure 5, respectively. As shown in Figure 5a, the four different catalysts have a certain adsorption effect on MO. After $30 \mathrm{~min}$, the adsorption effect decreased. Approximately 20\% of MO was removed in $30 \mathrm{~min}$ and 30\% in $2 \mathrm{~h}$. Therefore, the dark reaction time was set to half an hour in subsequent experiments.

(a)

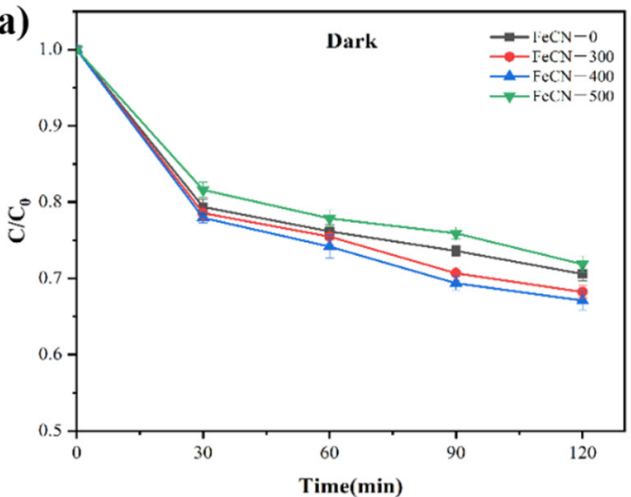

(c)

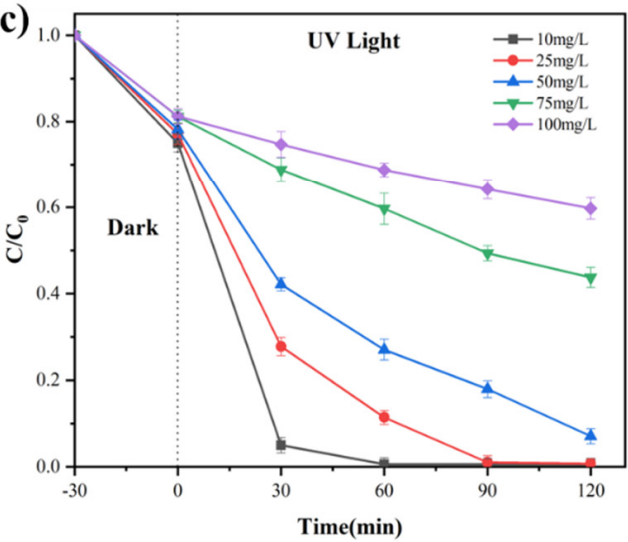

(b)

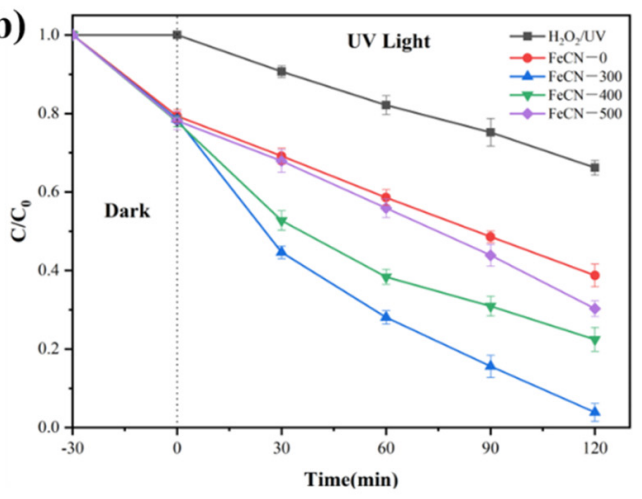

(d)

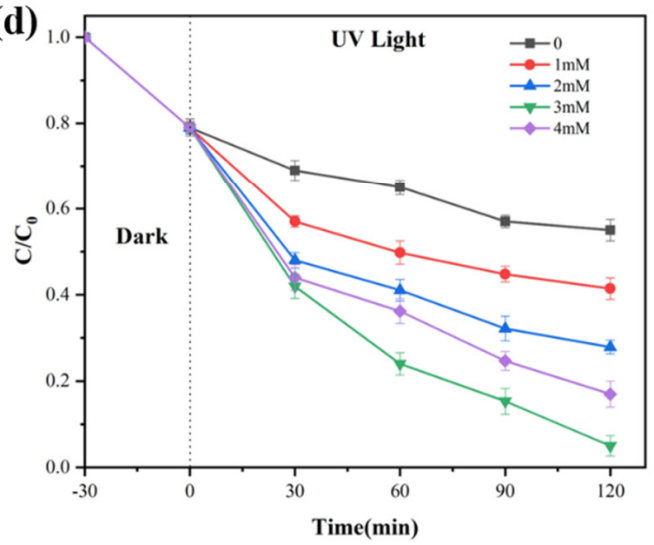

Figure 5. (a) Adsorption of $\mathrm{MO}$ under four different catalytic conditions ([Catalyst] $=0.2 \mathrm{~g} / \mathrm{L}$, $[\mathrm{MO}]=50 \mathrm{mg} / \mathrm{L})$. (b) Degradation of methyl orange under four different catalytic conditions and $\mathrm{H}_{2} \mathrm{O}_{2} / \mathrm{UV}$ condition ([Catalyst $]=0.2 \mathrm{~g} / \mathrm{L},[\mathrm{MO}]=50 \mathrm{mg} / \mathrm{L},\left[\mathrm{H}_{2} \mathrm{O}_{2}\right]=3 \mathrm{mM}$ ). (c) Effect of methyl orange concentration $\left([\mathrm{FeCN}-300]=0.2 \mathrm{~g} / \mathrm{L},\left[\mathrm{H}_{2} \mathrm{O}_{2}\right]=3 \mathrm{mM}\right)$. (d) Effect of $\mathrm{H}_{2} \mathrm{O}_{2}$ concentration $([\mathrm{FeCN}-300]=0.2 \mathrm{~g} / \mathrm{L},[\mathrm{MO}]=50 \mathrm{mg} / \mathrm{L})$.

The efficiency of the catalysts prepared at different calcination temperatures was compared, and the results were shown in Figure 5b. We found that the addition of each catalyst led to a significant improvement in the degradation of MO. The catalyst prepared by calcination at $300{ }^{\circ} \mathrm{C}$ had the best $\mathrm{MO}$ degradation compared those prepared at $400{ }^{\circ} \mathrm{C}$ and $500{ }^{\circ} \mathrm{C}$. We suggested that the excessively high calcination temperature destroyed the organic functional groups in the catalyst, resulting in the decline of catalytic efficiency. The optimal catalyst (FeCN-300) was selected for the following experiments.

Keeping the $\mathrm{H}_{2} \mathrm{O}_{2}$ concentration constant at $3 \mathrm{mM}$, the effect of the initial concentration of $\mathrm{MO}$ was investigated. As shown in Figure $5 \mathrm{c}$, with the initial concentration of $\mathrm{MO}$ continuously increasing, the degradation of $\mathrm{MO}$ constantly decreased. When the initial concentration of $\mathrm{MO}$ was $50 \mathrm{mg} / \mathrm{L}$, the removal of $\mathrm{MO}$ reached $92 \%$. When the increasing the initial concentration of $\mathrm{MO}$ was maintained, the catalytic efficiency was significantly reduced. Consequently, $50 \mathrm{mg} / \mathrm{L}$ was selected as the optimal initial concentration of MO.

The optimal $\mathrm{H}_{2} \mathrm{O}_{2}$ concentration required to maximize $\mathrm{MO}$ degradation was also evaluated. The results were shown in Figure 5d. The degradation of $\mathrm{MO}$ was increased, with the $\mathrm{H}_{2} \mathrm{O}_{2}$ concentration reaching an optimal value at $3 \mathrm{mM}$. When the $\mathrm{H}_{2} \mathrm{O}_{2}$ concentration increased further, the degradation efficiency decreased instead. Excessive hydrogen 
peroxide would act as photoelectron and free radical scavengers, affecting the degradation efficiency [32,33].

According to above batch experiments, the optimal parameters were obtained $\left([\mathrm{FeCN}-300]=0.2 \mathrm{~g} / \mathrm{L},\left[\mathrm{H}_{2} \mathrm{O}_{2}\right]=3 \mathrm{mM},[\mathrm{MO}]=50 \mathrm{mg} / \mathrm{L}\right)$. Compared with the previous study in Table 2, to obtain the high degradation efficiency, the amount of catalyst and hydrogen peroxide used in our work was much lower with the same concentration of the pollutants.

Table 2. Comparison of photocatalytic degradation performance.

\begin{tabular}{|c|c|c|c|c|}
\hline $\begin{array}{l}\text { Catalyst } \\
\text { Dosage }\end{array}$ & $\begin{array}{c}\qquad \mathrm{H}_{2} \mathrm{O}_{2} \\
\text { Concentration }\end{array}$ & $\begin{array}{l}\text { Contaminant/ } \\
\text { Concentration }\end{array}$ & $\begin{array}{c}\text { Time/ } \\
\text { Degradation Rate (\%) }\end{array}$ & References \\
\hline $0.5 \mathrm{~g} / \mathrm{L}$ & $195.88 \mathrm{mM}$ & $\begin{array}{l}\text { Methyl orange/ } \\
32.7 \mathrm{mg} / \mathrm{L}\end{array}$ & $90 \mathrm{~min} />90 \%$ & {$[21]$} \\
\hline $2.5 \mathrm{~g} / \mathrm{L}$ & $14.68 \mathrm{mM}$ & $\begin{array}{l}\text { Methylene blue/ } \\
50 \mathrm{mg} / \mathrm{L} \\
\text { Methyl orange/ } \\
50 \mathrm{mg} / \mathrm{L}\end{array}$ & $\begin{array}{l}150 \min / 95 \% \\
60 \min / 99 \%\end{array}$ & [22] \\
\hline $0.75 \mathrm{~g} / \mathrm{L}$ & $5.5 \mathrm{mM}$ & $\begin{array}{l}\text { amaranth dye/ } \\
50 \mathrm{mg} / \mathrm{L}\end{array}$ & $420 \mathrm{~min} / 98 \%$ & [34] \\
\hline $1 \mathrm{~g} / \mathrm{L}$ & $0.01 \mathrm{mM}$ & $\begin{array}{l}\text { Methylene blue/ } \\
10 \mathrm{mg} / \mathrm{L}\end{array}$ & $60 \min / 100 \%$ & [35] \\
\hline $1 \mathrm{~g} / \mathrm{L}$ & $1.96 \mathrm{mM}$ & $\begin{array}{c}\text { Methylene blue/ } \\
50 \mathrm{mg} / \mathrm{L}\end{array}$ & $80 \mathrm{~min} / 78 \%$ & [36] \\
\hline $0.2 \mathrm{~g} / \mathrm{L}$ & $3 \mathrm{mM}$ & $\begin{array}{c}\text { Methyl orange/ } \\
50 \mathrm{mg} / \mathrm{L}\end{array}$ & $120 \mathrm{~min} / 93 \%$ & This work \\
\hline
\end{tabular}

In the process of photo-Fenton degradation experiments, photo-induced electrons $\left(\mathrm{e}^{-}\right)$, photo-induced holes $\left(\mathrm{h}^{+}\right)$, hydroxyl radicals $(\bullet \mathrm{OH})$, and superoxide anion radicals $\left(\bullet \mathrm{O}_{2}{ }^{-}\right)$ are considered to be the main active species [37]. To analyze their contribution, quenching tests were conducted. As illustrated in Figure 6a, TEMPO, EDTA-2Na, $\mathrm{AgNO}_{3}, \mathrm{TBA}$, and $\mathrm{BQ}$ were used as scavengers of free radicals $\mathrm{h}^{+}, \mathrm{e}^{-}, \bullet \mathrm{OH}$, and $\bullet \mathrm{O}_{2}{ }^{-}$, respectively. The degradation of MO decreased sharply to $40.7 \%$ after TEMPO was added, indicating that the degradation of $\mathrm{MO}$ was mainly caused by free radicals. When the $\mathrm{e}^{-}$was scavenged by $\mathrm{AgNO}_{3}$, the degradation of $\mathrm{MO}$ was $73.7 \%$, hinting at the limited contribution of $\mathrm{e}^{-}$. Similarly, when the $\mathrm{h}^{+}, \bullet \mathrm{O}_{2}{ }^{-}$and $\bullet \mathrm{OH}$ were captured, the degradations of $\mathrm{MO}$ were $65.3 \%, 59.1 \%$, and $45.2 \%$, respectively. Hence, the effect of these reactivity species on the degradation of $\mathrm{MO}$ is $\bullet \mathrm{OH}>\bullet \mathrm{O}_{2}^{-}>\mathrm{h}^{+}>\mathrm{e}^{-}$.

The electron spin resonance (ESR) method with DMPO spin trap was used to identify possible free radical species in the photo-Fenton processes [38]. As illustrated in Figure 6b, four peaks with an intensity of 1:2:2:1 were observed in the photo-Fenton process, corresponding to the generation of $\bullet \mathrm{OH}$, while no signal was found for the formation of $\bullet \mathrm{OH}$ under dark conditions. The results confirmed that, under the synergistic effect of ultraviolet light and hydrogen peroxide, the FeCN-300 catalyzed the generation of hydroxyl free radicals to achieve the degradation of pollutants.

The recyclability of catalysts is crucial for practical application [39]. As can be seen from Figure 7, after five cycles, the degradation of $\mathrm{MO}$ and TOC decreased slightly, reaching approximately $89.5 \%$ and $83.1 \%$ under identical conditions. The results demonstrated that the FeCN-300 had good catalytic performance and stability under UV light irradiation. 
(a)

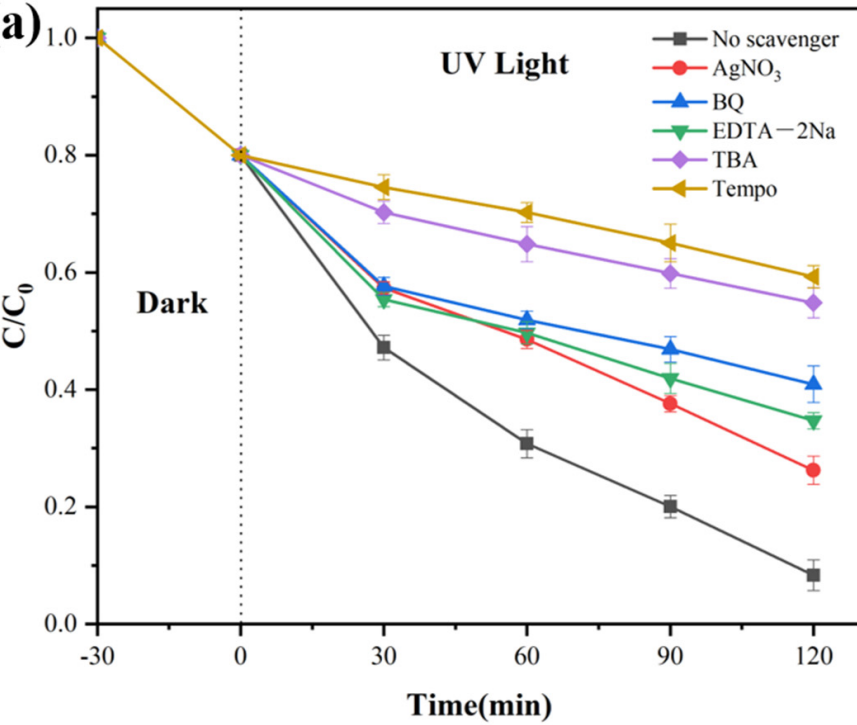

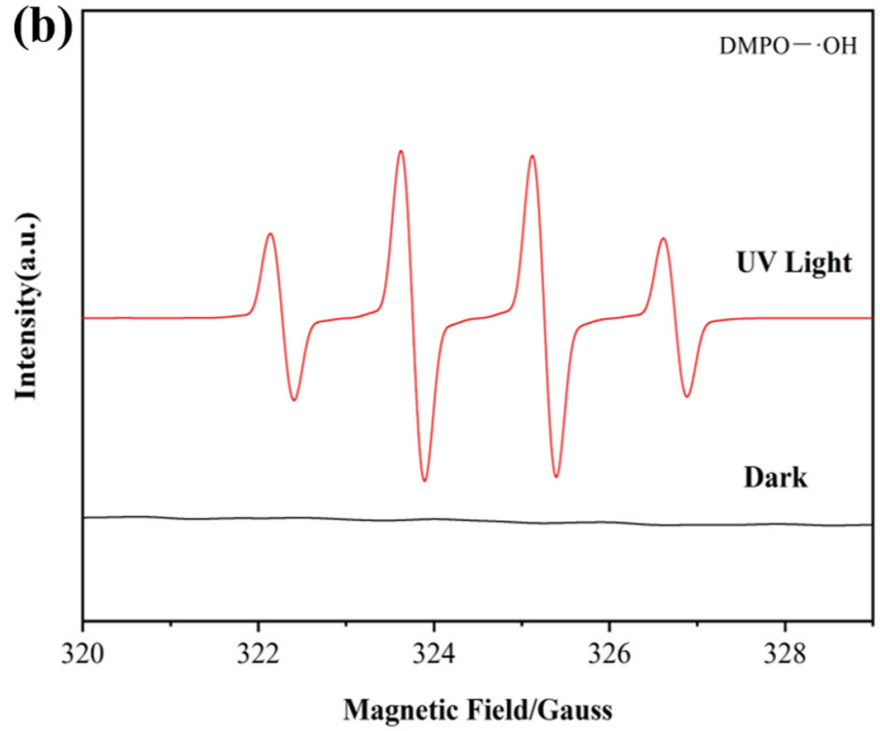

Figure 6. (a) $\mathrm{MO}$ removal in quenching tests $\left([\mathrm{FeCN}-300]=0.2 \mathrm{~g} / \mathrm{L}\right.$, $[\mathrm{MO}]=50 \mathrm{mg} / \mathrm{L}$, $\left.\left[\mathrm{H}_{2} \mathrm{O}_{2}\right]=3 \mathrm{mM}\right)$. (b) ESR spectra of reactive radicals.

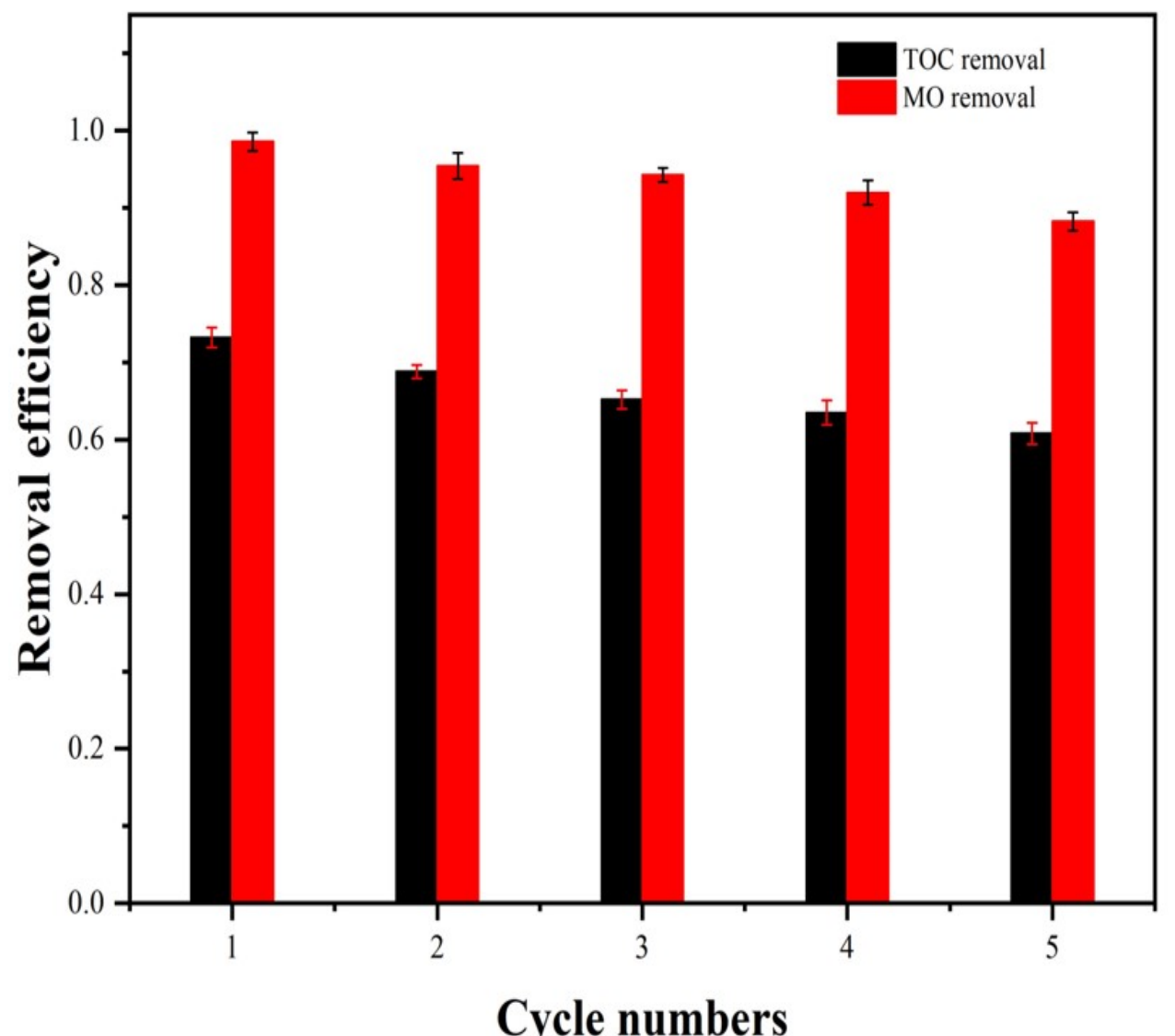

Figure 7. Five consecutive runs FeCN-300 catalyst. (Experimental conditions: $[\mathrm{MO}]=50 \mathrm{mg} / \mathrm{L}$, $\left[\mathrm{H}_{2} \mathrm{O}_{2}\right]=3 \mathrm{mM}$, [Catalyst $]=0.2 \mathrm{~g} / \mathrm{L}$, and $300 \mathrm{~W}$ xenon lamp).

\section{Conclusions}

In summary, we utilized sludge generated in dyeing wastewater to prepare heterogeneous photo-Fenton catalysts through a one-step pyrolysis method at different temperatures, and evaluated these catalysts with the degradation of methyl orange. The FeCN-300 
catalyst exhibited the best effect with $92 \%$ removal of pollutant under optimum conditions $\left([\mathrm{MO}]=50 \mathrm{mg} / \mathrm{L},\left[\mathrm{H}_{2} \mathrm{O}_{2}\right]=3 \mathrm{mM}, 30 \mathrm{~min}\right.$ adsorption, $2 \mathrm{~h}$ photo-Fenton). The catalyst also showed good stability with approximately $90 \%$ removal of pollutants after five cycles. The main component of the FeCN-300 catalyst is $\mathrm{Fe}_{3} \mathrm{O}_{4}$, and the main free radical to degrade pollutants is $\bullet \mathrm{OH}$. This work provides new insights into the resource utilization of iron-containing sludge.

Supplementary Materials: The following supporting information can be downloaded at: https:// www.mdpi.com/article/10.3390/w14040629/s1, Figure S1: (a) Adsorption of MO under four different catalytic conditions ([Catalyst $]=0.2 \mathrm{~g} / \mathrm{L},[\mathrm{MO}]=50 \mathrm{mg} / \mathrm{L}$ ). (b) Degradation of methyl orange under four different catalytic conditions and $\mathrm{H}_{2} \mathrm{O}_{2} / \mathrm{UV}$ condition ([Catalyst] $=0.2 \mathrm{~g} / \mathrm{L}$, $[\mathrm{MO}]=50 \mathrm{mg} / \mathrm{L}$, $\left.\left[\mathrm{H}_{2} \mathrm{O}_{2}\right]=3 \mathrm{mM}\right)$. (c) Effect of methyl orange concentration $\left([\mathrm{FeCN}-300]=0.2 \mathrm{~g} / \mathrm{L},\left[\mathrm{H}_{2} \mathrm{O}_{2}\right]=3 \mathrm{mM}\right)$. (d) Effect of $\mathrm{H}_{2} \mathrm{O}_{2}$ concentration $([\mathrm{FeCN}-300]=0.2 \mathrm{~g} / \mathrm{L}$, $[\mathrm{MO}]=50 \mathrm{mg} / \mathrm{L})$.

Author Contributions: Conceptualization, X.L. and H.-L.L.; methodology, X.L. and H.-L.L.; software, X.L.; validation, X.L. and K.-P.C. and X.C.; formal analysis, X.L.; investigation, X.L.; resources, K.-P.C., Z.-L.D., B.W. and X.C.; data curation, X.L.; writing-original draft preparation, X.L. and H.-L.L.; writing-review and editing, X.L. and X.C.; supervision, K.-P.C. and X.C. All authors have read and agreed to the published version of the manuscript.

Funding: This research received no external funding.

Institutional Review Board Statement: Not applicable.

Informed Consent Statement: Not applicable.

Data Availability Statement: Not applicable.

Acknowledgments: The authors acknowledge the financial support from the National Key R\&D Program of China (2019YFC0408500), and Key Science and Technology Projects of Anhui Province (202003a07020004).

Conflicts of Interest: The authors declare no conflict of interest.

\section{References}

1. Mani, S.; Chowdhary, P.; Bharagava, R.N. Textile Wastewater Dyes: Toxicity Profile and Treatment Approaches. Emerging and Eco-friendly Approaches for Waste Management; Springer: Berlin/Heidelberg, Germany, 2019; pp. 219-244.

2. Li, H.; Wang, Y.; Wang, Y.; Wang, H.; Sun, K.; Lu, Z. Bacterial degradation of anthraquinone dyes. J. Zhejiang Univ.-SCI. B 2019, 20, 528-540. [CrossRef] [PubMed]

3. Zhang, X. Selective separation membranes for fractionating organics and salts for industrial wastewater treatment: Design strategies and process assessment. J. Membr. Sci. 2022, 643, 120052. [CrossRef]

4. Torrades, F.; García-Montaño, J. Using central composite experimental design to optimize the degradation of real dye wastewater by Fenton and photo-Fenton reactions. Dyes Pigment. 2014, 100, 184-189. [CrossRef]

5. Gu, L.; Nie, J.-Y.; Zhu, N.; Wang, L.; Yuan, H.-P.; Shou, Z. Enhanced Fenton's degradation of real naphthalene dye intermediate wastewater containing 6-nitro-1-diazo-2-naphthol-4-sulfonic acid: A pilot scale study. Chem. Eng. J. 2012, 189, 108-116. [CrossRef]

6. Chen, X.; Liu, X.; Wang, H.B.; Cui, K.P.; Weerasooriya, R.; He, S.L.; Li, G.H.; Pan, J.; Zhou, K. Ce ${ }^{3+}$ triggers Fenton-like processes in neutral solutions for effective catechol degradation. Environ. Eng. Res. 2022, 27, 200519. [CrossRef]

7. Yang, G.; Zhang, G.; Wang, H. Current state of sludge production, management, treatment and disposal in China. Water Res. 2015, 78, 60-73. [CrossRef] [PubMed]

8. Wang, J.L.; Tang, J.T. Fe-based Fenton-like catalysts for water treatment: Catalytic mechanisms and applications. J. Mol. Liq. 2021, 332, 115755. [CrossRef]

9. He, L.; Li, M.X.; Chen, F.; Yang, S.S.; Ding, J.; Ding, L.; Ren, N.Q. Novel coagulation waste-based Fe-containing carbonaceous catalyst as peroxymonosulfate activator for pollutants degradation: Role of ROS and electron transfer pathway. J. Hazard. Mater. 2021, 417, 126113. [CrossRef]

10. Zeng, H.P.; Zhai, L.X.; Qiao, T.D.; Zhang, J.; Li, D. Removal of As(V) by a core-shell magnetic nanoparticles synthesized with iron-containing water treatment residuals. Coll. Surf. A 2021, 627, 127074. [CrossRef]

11. Xia, Y.; Tang, Y.; Shih, K.; Li, B. Enhanced phosphorus availability and heavy metal removal by chlorination during sewage sludge pyrolysis. J. Hazard. Mater. 2020, 382, 121110. [CrossRef]

12. Zhu, R.; Xia, J.; Zhang, H.; Kong, F.; Hu, X.; Shen, Y.; Zhang, W.-H. Synthesis of magnetic activated carbons from black liquor lignin and Fenton sludge in a one-step pyrolysis for methylene blue adsorption. J. Environ. Chem. Eng. 2021, 9, 106538. [CrossRef] 
13. Yuan, S.-J.; Dai, X.-H. Sewage sludge-based functional nanomaterials: Development and applications. Environ. Sci. Nano 2017, 4, 17-26. [CrossRef]

14. Yuan, S.-J.; Dai, X.-H. Facile synthesis of sewage sludge-derived mesoporous material as an efficient and stable heterogeneous catalyst for photo-Fenton reaction. Appl. Catal. B Environ. 2014, 154, 252-258. [CrossRef]

15. Huang, Y.-F.; Huang, Y.-Y.; Chiueh, P.-T.; Lo, S.-L. Heterogeneous Fenton oxidation of trichloroethylene catalyzed by sewage sludge biochar: Experimental study and life cycle assessment. Chemosphere 2020, 249, 126139. [CrossRef] [PubMed]

16. Gan, Q.; Hou, H.; Liang, S.; Qiu, J.; Tao, S.; Yang, L.; Yu, W.; Xiao, K.; Liu, B.; Hu, J.; et al. Sludge-derived biochar with multivalent iron as an efficient Fenton catalyst for degradation of 4-Chlorophenol. Sci. Total Environ. 2020, 725, 138299. [CrossRef]

17. Khan, S.A.; Zahera, M.; Khan, I.A.; Khan, M.S.; Azam, A.; Arshad, M.; Syed, A.; Nasif, O.; Elgorban, A.M. Photocatalytic degradation of methyl orange by cadmium oxide nanoparticles synthesized by the sol-gel method. Optik 2021, $251,168401$. [CrossRef]

18. Omri, A.; Hamza, W.; Benzina, M. Photo-Fenton oxidation and mineralization of methyl orange using Fe-sand as effective heterogeneous catalyst. J. Photochem. Photobiol. A Chem. 2020, 393, 112444. [CrossRef]

19. Velusamy, K.; Periyasamy, S.; Kumar, P.S.; Jayaraj, T.; Gokulakrishnan, M.; Keerthana, P. Transformation of aqueous methyl orange to green metabolites using bacterial strains isolated from textile industry effluent. Environ. Technol. Innov. 2022, $25,102126$. [CrossRef]

20. Wang, Y.; Gao, Y.; Chen, L.; Zhang, H. Goethite as an efficient heterogeneous Fenton catalyst for the degradation of methyl orange. Catal. Today 2015, 252, 107-112. [CrossRef]

21. Urmi, S.A.; Kurny, A.; Gulshan, F. Decolorization of methyl orange using mill scale by photo-Fenton reaction. Procedia Eng. 2015, 105, 844-851. [CrossRef]

22. Izghri, Z.; Enaime, G.; Eouarrat, M.; Chahid, L.; el Gaini, L.; Baçaoui, A.; Yaacoubi, A. Hydroxide sludge/hydrochar-Fe composite catalysts for photo-fenton degradation of dyes. J. Chem. 2021, 2021, 5588176. [CrossRef]

23. Zhang, H.-M.; Zhao, Y.; Zhang, Y.; Zhang, M.; Cheng, M.; Yu, J.; Liu, H.; Ji, M.; Zhu, C.; Xu, J. Fe ${ }_{3} \mathrm{O}_{4}$ encapsulated in porous carbon nanobowls as efficient oxygen reduction reaction catalyst for Zn-air batteries. Chem. Eng. J. 2019, 375, 122058. [CrossRef]

24. Lee, J.-H.; Kwon, J.-S.; Om J-y Kim, Y.-H.; Choi, E.-H.; Kim, K.-M.; Kim, K.-N. Cell immobilization on polymer by air atmospheric pressure plasma jet treatment. JPN. J. Appl. Physics 2014, 53, 086202. [CrossRef]

25. Daniells, S.; Overweg, A.; Makkee, M.; Moulijn, J. The mechanism of low-temperature $\mathrm{CO}$ oxidation with $\mathrm{Au} / \mathrm{Fe}_{2} \mathrm{O}_{3}$ catalysts: A combined Mössbauer, FT-IR, and TAP reactor study. J. Catal. 2005, 230, 52-65. [CrossRef]

26. Fekri, L.Z.; Nikpassand, M.; Goldoost, M. Synthesis, experimental and DFT studies on crystal structure, FT-IR, 1 H, and 13 C NMR spectra, and evaluation of aromaticity of three derivatives of xanthens. Rus. J. Gen. Chem. 2013, 83, 2352-2360. [CrossRef]

27. Abdulkadir, I.; Uba, S.; Almustapha, M. A rapid method of crude oil analysis using FT-IR spectroscopy. Nig. J. Basic Appl. Sci. 2016, 24, 47-55. [CrossRef]

28. Du, P.; Bao, Y.; Guo, C.; Wu, L.; Pan, J.; Zhao, C.; Ma, F.-X.; Lu, J.; Li, Y.Y. Design of Fe, N co-doped multi-walled carbon nanotubes for efficient oxygen reduction. Chem. Commun. 2020, 56, 14467-14470. [CrossRef]

29. Wu, Q.; Chen, M.; Chen, K.; Wang, S.; Wang, C.; Diao, G. $\mathrm{Fe}_{3} \mathrm{O}_{4}$-based core/shell nanocomposites for high-performance electrochemical supercapacitors. J. Mater. Sci. 2016, 51, 1572-1580. [CrossRef]

30. Wilson, D.; Langell, M.A. XPS analysis of oleylamine/oleic acid capped $\mathrm{Fe}_{3} \mathrm{O}_{4}$ nanoparticles as a function of temperature. Appl. Surf. Sci. 2014, 303, 6-13. [CrossRef]

31. Thommes, M.; Kaneko, K.; Neimark, A.V.; Olivier, J.P.; Rodriguez-Reinoso, F.; Rouquerol, J.; Sing, K.S. Physisorption of gases, with special reference to the evaluation of surface area and pore size distribution (IUPAC Technical Report). Pure Appl. Chem. 2015, 87, 1051-1069. [CrossRef]

32. Dong, C.; Ji, J.; Shen, B.; Xing, M.; Zhang, J. Enhancement of $\mathrm{H}_{2} \mathrm{O}_{2}$ Decomposition by the Co-catalytic Effect of WS 2 on the Fenton Reaction for the Synchronous Reduction of Cr (VI) and Remediation of Phenol. Environ. Sci. Technol. 2018, 52, 11297-11308. [CrossRef] [PubMed]

33. Hoffmann, M.R.; Martin, S.T.; Choi, W.; Bahnemann, D.W. Environmental applications of semiconductor photocatalysis. Chem. Rev. 1995, 95, 69-96. [CrossRef]

34. Grassi, P.; Drumm, F.C.; Georgin, J.; Franco, D.S.P.; Foletto, E.L.; Dotto, G.L.; Jahn, S.L. Water treatment plant sludge as iron source to catalyze a heterogeneous photo-Fenton reaction. Environ. Technol. Innov. 2020, 17, 100544. [CrossRef]

35. Wang, Q.; Tian, S.; Long, J.; Ning, P. Use of Fe(II)Fe(III)-LDHs prepared by co-precipitation method in a heterogeneous-Fenton process for degradation of Methylene Blue. Catal. Today 2014, 224, 41-48. [CrossRef]

36. Zhou, G.; Fang, F.; Chen, Z.; He, Y.; Sun, H.; Shi, H. Facile synthesis of paper mill sludge-derived heterogeneous catalyst for the Fenton-like degradation of methylene blue. Catal. Commun. 2015, 62, 71-74. [CrossRef]

37. Zhang, Q.; Jiang, L.; Wang, J.; Zhu, Y.; Pu, Y.; Dai, W. Photocatalytic degradation of tetracycline antibiotics using three-dimensional network structure perylene diimide supramolecular organic photocatalyst under visible-light irradiation. Appl. Catal. B Environ. 2020, 277, 119122. [CrossRef] 
38. Li, X.Y.; Cui, K.P.; Guo, Z.; Yang, T.T.; Cao, Y.; Xiang, Y.P.; Chen, H.H.; Xi, M.F. Heterogeneous Fenton-like degradation of tetracyclines using porous magnetic chitosan microspheres as an efficient catalyst compared with two preparation methods. Chem. Eng. J. 2020, 379, 122324. [CrossRef]

39. Molnar, A. Efficient, selective, and recyclable palladium catalysts in carbon-carbon coupling reactions. Chem. Rev. 2011, 111, 2251-2320. [CrossRef] 